\title{
Building a Love Character of the Cultural Environment Through Historical Learning Hudaidah ${ }^{1 *}$, Retno Susanti ${ }^{2}$, Dian Sri Andriani ${ }^{3}$
}

\author{
${ }^{1}$ Department of History Education, Sriwijaya University, \\ ${ }^{2}$ Department of History Education, Sriwijaya University, \\ ${ }^{3}$ Department of Out-of-School Education, Sriwijaya University, \\ Email: *hudaidah @ fkip.unsri.ac.id,
}

\begin{abstract}
The focus of this article is to see how learning history can build character, that is, the character of loving the cultural environment. The problem in this article is about the role of historical learning in building a love character for the cultural environment. Then the purpose of this article is to find out how the role of historical learning in building a love character for the cultural environment. Building the character of loving the cultural environment is one of the most important roles, so that the character that is owned is not easily eroded, one of these things can be done through historical learning. Through historical learning, the culture in the community is identified, documented and studied again, this process can increase love for culture and can preserve it so that it is not lost from people's lives. The data in this article were obtained through the review literature, through this literature review it was known that cultural-based historical learning could play an important role in building the character of love for culture.
\end{abstract}

Keywords: Characters Love the Cultural Environment, Learning History

\section{INTRODUCTION}

South Sumatra is very rich in living cultures that come from various times, which spread in almost all districts and cities. Complete cultural treasures from prehistoric times, Hindu-Buddhist times, Islamic times, Dutch and Japanese colonial times, and the era of independence can be found in South Sumatera [1]. These cultural treasures have values that reflect the cultural life of the community from time to time that need to be preserved in order to provide benefits to contemporary life.

Learning from these cultural treasures contains cultural values that need to be continued and preserved, so that the next generation can enjoy them and can make valuable lessons about their ancestors.

Based on the facts and research that has been done by many experts, many cultural treasures in society have been lost due to the entry of various external cultures that have eroded them, this is very sad and it is unfortunate that culture must continue to live in its supporting communities [2]. Even though the fact is that in a culture, local wisdom values are usually contained which can become the identity of the community [4]. If many cultures are lost, this is very dangerous for the survival of a society. Therefore, cultural preservation is very important to day, in some cases the Indonesian culture is often found which is later claimed by other nations [5]. This must be the concern of various parties so that it does not happen again in society, including the people of South Sumatra so that local culture is not eroded by the flow of globalization and must continue to strive so that the culture that lives in the community is not lost.

The most real effort to preserve culture is through the world of education by building a love of culture character. The world of education should prioritize cultural preservation efforts by continuing to develop a learning process that pays attention to cultural preservation [6]. Learning that is close enough to the repertoire of culture is history learning [7]. Especially in tertiary institutions, learning history can be at the forefront of building a love-culture character. In several tertiary institutions that have Teacher Training 
Institutions with study programs or majoring in Historical Education. Learning history is a history teacher-producing institution that will teach history lessons in schools. Therefore, the historical education study program has a very important role in building a love character for the cultural environment. Because history learning needs to be designed to build the character of students who love the culture around them, they will then transfer this character to students after becoming teachers in society [8].

Based on this, the problem to be raised through this paper is how the role of historical learning in building the character of love for the cultural environment, while the aim is to find out how the role of historical learning in building the love of the cultural environment.

\section{METHOD}

The method used in this research is descriptive method with a percentage. The data was obtained by distributing questionnaires to students of history education Sriwijaya University with Google Form assistance. Attitude questionnaires are used to measure the students' character of cultural love by categories, as shown in the following table [9]:

Table 1 Alternative Answers to the cultural Love Questionnaire:

\begin{tabular}{cc}
\hline Statement & Score \\
\hline Strongly Agree (SA) & 5 \\
\hline Agree (A) & 4 \\
\hline Less Agree (LA) & 3 \\
\hline Dis Agree (DA) & 2 \\
\hline $\begin{array}{c}\text { Strongly Dis Agree } \\
\text { (DSA) }\end{array}$ & 1 \\
\hline
\end{tabular}

Furthermore, the data from the questionnaire were analyzed by percentage calculating modified from Riduwan's [10].

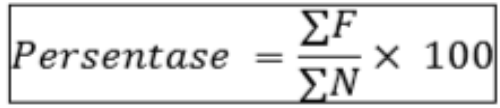

Then described to see the character of love for the cultural environment the students.

\section{RESULT AND DISCUSSION}

As a simple attempt to describe the relationship between historical learning and the building of the character of love for the cultural environment, it is described as follows:

\subsection{Character Building}

Education is a continuous effort made in order to improve the quality of the nation, education that is carried out comprehensively in people's lives can have an impact on changes in the quality of life of the community [11]. Learning from various worlds, call it Japan after World War II, the Japanese emperor looked for teachers who were still there and started building his war-torn country by developing education [12]. It is more interesting that Japan develops character-based education, so that to this day Japanese society is known for its excellent character, for example, religious character, discipline, and hard work. This distinctive character has become a symbol of Japanese society.

In general, education is aimed at creating intelligent Indonesian people and having noble morals, even when referring to the conception of the curriculum, education involves three aspects, namely affection (character/character), cognitive (knowledge) and psychomotoric (skills) [13]. Actually character education is not a new concept in the education of the Indonesian nation, Indonesian education figure $\mathrm{Ki}$ Hajar Dewantara has initiated this conception since the early twentieth century, defines education as an effort to advance children's character, mind and body, in order to advance the perfection of life and bring life to life. children in harmony with nature and society. It can be imagined if education only produces intelligent people but without character, then those who attend are versatile but heartless robots because they do not have character [14].

So character education is a systematic effort to instill character values, act with positive values, both towards God Almighty, self, neighbor, environment, and nationality [15]. In fact, according to Rakhmat [16]; Hidayat and Abdillah [17], education has two main missions, namely "transfer of values" and "transfer of knowledge". At point one, it is clear that education is an effort to inherit values, followed by the cultivation of knowledge. Lickona has the same opinion that character education emphasizes the importance of the three components of good character, namely moral knowing or knowledge about morals, moral feelings or feelings about moral and moral action or moral actions [18].

Education as an enculturation process functions to pass the values and achievements of the past to future generations [19]. These 
values and achievements are the pride of the nation and make that nation known by other nations. In addition to inheriting, education also has a function to develop cultural values and past achievements into national cultural values that are suitable for present and future life, as well as develop new achievements that become new characteristics of the nation [20]. In line with the above opinion, education is an arena for re-activating the noble character of the Indonesian nation, awakening a nation's character and internalizing the two aspects above, namely the successful re-activation of past cultures and innovative and competitive characters into all aspects of the nation's life. [21]

Therefore, Ki Hajar Dewantara said that culture is the basis or basis of education. the functional relationship between education and culture which contains two main things [22], namely: First, it is reflective, education is a picture of ongoing culture. Second, it is progressive, education seeks to make reforms, innovations so that existing cultures can achieve advancement. These two things, in line with the duties and functions of education, are to continue or inherit culture and change and develop that culture to achieve the advancement of human life. This is where character education is an endeavor of inheriting the values that exist to each individual as well as innovative and dynamic efforts in order to renew these values in a more advanced direction [23]. So education must be rooted in the culture that lives in the community so that they are not uprooted from the root of local cultural values [24], in concept of education known as (context of learning).

Speak to character values, the Indonesian nation has long been known as a great nation with a religious character, tough, unyielding, hard work, honest and disciplined. Unfortunately, these characters are starting to be eroded by the current of globalization. Therefore, in the present era, education is reexploring the cultural values that exist in society to be reactivated in social life through this character education.

\subsection{History Learning}

One of the lessons that have a big task in multiplying the cultural values and character that are brought into the classroom to be actualized by students is history learning. The history education expert who most often reviews character education associated with history learning is Hamid Hasan. According to him, history learning has a strategic meaning in shaping dignified character and shaping Indonesian people who have a sense of nationality and love for the country. This is certainly in line with the Minister of National Education Regulation on historical education as a subject that has great potential for developing character education [25]. The character education process is implemented in history learning in the following ways: 1) the value transformation stage, where education informs the character values to students, in the form of verbal communication. 2) the value transaction stage, at this stage the educator presents character values with reciprocal communication; 3) the trans internalization stage, which is the most important stage, namely instilling character values in students, so that positive personalities and mental attitudes of students are formed and can be implemented in their daily lives [26].

Learning history is not memorizing historical facts but must be able to create wise students, be able to learn from all historical events and draw positive values from each of these historical events so that a positive character is formed after learning history. If this happens, the goal of learning history has been successful, namely "history make man wise" [27]. This is done continuously and reflects deeply on students so that it becomes a moral decision (Moral Choice) and is carried out in life in the form of real action, carried out practically and reflectively. If it is done for a long time, it becomes (custom) a habit and forms one's character [28]

Then a fundamental question arises how learning history can produce wise learners? To answer this question a simple illustration, humans from time to time cannot be separated from the culture that lives in society. Cultural values are the truth and are recognized by the supporting community, used as the basis for giving meaning to a concept and meaning in communication between community members. The cultural position that is so important in people's lives has become a source of values from cultural education and national character [29]. In other words, history learning becomes a medium to pass cultural values on to students, as members of society, and citizens who are religious, nationalist, productive and creative [30].

The current phenomenon of globalization affects the culture of society, for example: loss of native culture of a region, erosion of the love of culture and nationalism of the younger generation, decreased sense of 
nationalism and patriotism, loss of kinship and mutual cooperation, loss of self-confidence and a westernized lifestyle [31]. So history learning must be able to show self-belonging attitude towards culture or a sense of belonging to culture.

In other words, character education through history learning is education that develops cultural values and national character, by increasing knowledge skills accompanied by cultivating character and cultural values to form a strong character in students. History learning functions as a cultural preserver through early introduction to students [32].

The culture that exists in various regions is a national cultural asset, therefore it must be the attention of every child of the nation in order to build national identity and build national competitiveness. The community was shocked by the news of several national cultures that were claimed by other nations [33]. Culture is the whole system of ideas, actions, and human work in the context of community life which is made the property of humans by learning [34]. The culture that exists in the community, among others: customs, origins or historical places, language, food, clothing, tools, medicines, beliefs or beliefs, the environment and local communities, arts, local traditions and fochlor [35].

Preservation is an activity that is carried out continuously, to maintain the values of art and culture, traditional values by developing manifestations that are dynamic, flexible and selective, and adapt to situations and conditions that are always changing and developing [36]. Cultural preservation can occur if there is cultural awareness within the individual. The notion of cultural awareness is also known as cultural appreciation, which means awareness of artistic and cultural values. Awareness or appreciation of something because "something has a valuable value" in this case the value of art [37]. Efforts to find and collect traces of culture that actually reflect various aspects of human activity in the past. Because human activities in the past varied greatly, the traces left behind were also of various forms. The traces can be divided into: (1) non-material, namely various community institutions, customs, beliefs, traditions, occult things, fairy tales, language and others, , (2) material, namely various kinds of objects, artifacts and other items produced by humans, (3) written, namely handwritten in the form of letters, diaries, travel stories, manuscripts and prints in the form of newspapers, magazines, books and others,(4) representational (traces that represent other traces), for example a painting is a picture of a certain atmosphere contained in a portrait or painting, and (5) oral information from the perpetrator or witness [38]. Through history learning, a character of love for the cultural environment is built by trying to preserve it, with various love-culture activities.

The character of love for the cultural environment can be in the form of ways of thinking, behaving, and acting that shows high interest, loyalty, concern, and appreciation for culture [39]. To make it easier to understand the character of environmental love [40] through history learning, it can be seen in the following table:

Table 2 Characters Love the Cultural Environment

\begin{tabular}{lll}
\hline Number & Characters that appear & \multicolumn{1}{c}{ Examples of behavior } \\
\hline 1 & Interest of culture & Enjoyed learning the local culture \\
\hline 2 & Faithful of culture & Like to use the local culture \\
\hline 4 & Respect of the cultural values & Using the local culture properly \\
\hline 5 & Care of culture & Try to care and preserve culture \\
\hline 6 & Open attitude & $\begin{array}{l}\text { Appreciate and understand the other regional } \\
\text { cultures }\end{array}$ \\
\hline 7 & Responsive & $\begin{array}{l}\text { Developin the old culture into a new and } \\
\text { superior culture }\end{array}$ \\
\hline
\end{tabular}

Based on the study and table above, it can be illustrated that the pattern of the character of
Cultural love environment through the following chart: 
Chart 1 The pattern of development character cultural love environment

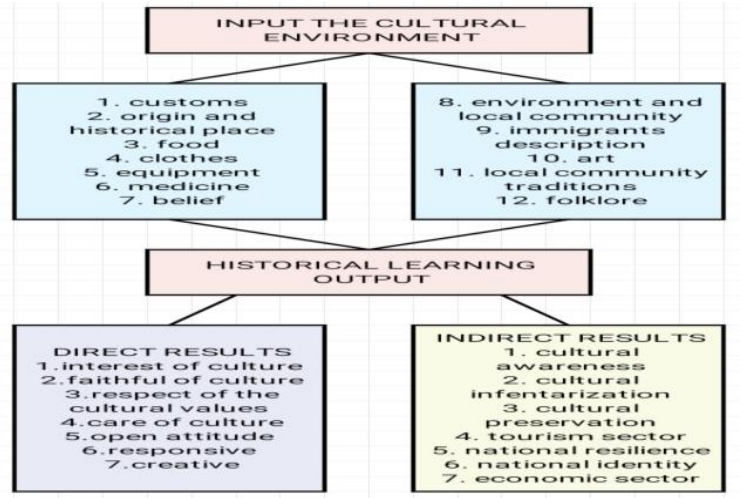

Source: Personal data, 2013

Through this research, the students' awareness of historical and regional culture was also measured using a questionnaire with the main indicators of the cultural love. The results of questionnaire are shown in the following table:

Table 3 Alternative Answers to the cultural Love Questionnaire

\begin{tabular}{lll}
\hline Number & Students & Persentage \\
\hline 1 & 50 & 90,62
\end{tabular}

Based on the table above, it can be seen that the percentage of the student questionnaire 90.62 is above the category $\geq 50.00$ so it is categorized that students have the character of love for the cultural environment are very good.

Thus this research also supports the learning theories used, including constructivist learning theory, cognitive theory, and behavioristic theory. The relevant theory is the constructivist theory [41], the learning process by seeing the interaction with the surrounding environment (local history) will bring out the character of students and will continuously have an impact on the character of love for the cultural environment and want to continue to preserve the culture of their respective regions.

This correlates with high knowledge of regional history and culture in South Sumatra, and will encourage the students building the character of love for the cultural environment be more creative and imaginative.

\section{CONGCLUSION}

The cultural collection contained in society must be preserved through historical learning, because based on the characteristics of historical learning, it cannot be separated from learning about cultural values that exist in society, therefore historical learning has an important role in developing the character of love for the cultural environment.

The character of love for the cultural environment that can be developed through historical learning is interest, loyalty, respect, openness, care, responsiveness and creativity. This character is carried out continuously so that it becomes a habit (custom) in students.

\section{ACKNOWLEDGMENTS}

The authors thank to Universitas Sriwijaya for giving us the oppotunity to encourage and facilitate authors to complete this competive research in 2020 year. Thanks also to the head departement of our studi program, who teaches and motivates the researchers to learn more abaout research methodology on research in history education.

\section{REFERENCES}

[1] Ardiwidjaya, Utomo and Rangkuti, 2013. Pengembangan Pariwisata Warisan Budaya Palembang, Yogyakarta: Kapel, pp. 2

[2] Ayu, Permata dan Rifianti, 2017. Sistem Perlindungan Sumber Daya Budaya Tak Benda di Palembang, Sumatera Selatan, Indonesia, in: Mimbar Hukum Journal, volume 29, nomor 2, Juni 2017, pp. 219

[3] Jumardi dan Pradita, Silvi Mei, 2017. Peranan Pelajaran Sejarah Dalam Pengembangan Karakter Siswa Melalui Pembelajaran Berbasis Nilai Sejarah 
Lokal di SMA Negeri 65 Jakarta Barat, in : Jurnal Pendidikan Sejarah 1 Vol. 6 No. 2 Juli 2017.

[4] Daniah, 2016. Kearifan Lokal (Local Wisdom) Sebagai Basis Pendidikan Karakter, in : Ar Raniry Ejournal.ac.id, pp.10

[5] 31 Agustus 2009. Produk Budaya Mendesak Dilindungi, in: Kompas Newspaper .

[6] Marjanto, Damardjati Kun, 2019. Transmission Of Cultural Values Through Institutions Of Traditional Education In Order To Support The Strengthening Of Character Education Program (Ppk), in : Patanjala Journal Vol. 11 No. 2 Juni 2019: $249-263$, pp. 258

[7] Mustika Zahroa, Sumardib, Marjono, 2017. The Implementation Of The Character Education In History Teaching, in : Historica Journal ISSN No. 2252-4673 Volume. 1 (2017) Issue. 1.

[8] Wiriatmadja, Rochiati.2002. Idealitas Pendidikan Sejarah Di Indonesia, Pendidikan Sejarah di Indonesia: Perspektif Lokal, Nasional, dan Global. (Bandung: Historia Utama Press, 2002), xi $+336 \mathrm{hlm}$ 1 , in : http://staffnew.uny.ac.id/

[9] Riduwan, 2007. Pengantar Statistika untuk Penelitian Pendidikan Sosial-Ekonomi Bisnis. Bandung: CV Alfabeta, p. 53.

[10]. Riduwan, 2007. Pengantar Statistika untuk Penelitian Pendidikan Sosial-Ekonomi Bisnis.

[11] Kochhar. 2008. Pembelajaran Sejarah. Jakarta: Grasindo.

[12] Wahyuni, Agung dan Wahyuni 2008.. Perkembangan Pendidikan Di Negara Jepang Pasca Perang Dunia II Dan Relevansinya Terhadap Pembelajaran Sejarah Di Sekolah Menengah Atas Program Studi Pendidikan Sejarah FKIP UNS, in : Candi Journal, volume 18, nomer 2, hlm 99

[13] Hudaidah, 2019. Bahan Ajar Mata Kuliah Evaluasi Pembelajaran Sejarah, Palembang: Noer Fikri, pp.20

[14] Maunah, Binti, 2015. Mplementasi Pendidikan Karakter Dalam Pembentukan Kepribadian Holistik Siswa, in : Pendidikan Karakter Journal \&bullet; April 2015 DOI 10.21831/jpk.v0i1.8615.

[15] Umami, Rizqy, Latifah, Nurul, dan Sholeha, Vera. 2018. Strategi Implementasi Pendidikan
Karakter Berbasis Budaya Di TK Laboratori Pedagogia Yogyakarta, in : PROSIDING SEMINAR PAUD_UAD_2018, eprints.uad.ac.id/12662/1.

[16] Omeri, Nopan, 2015. Pentingnya Pendidikan Karakter Dalam Dunia Pendidikan, in : Manajer Pendidikan Journal, Volume 9, Nomor 3, Juli 2015, hlm. 464-468.

[17] Rakhmat, Cece, tt. Menyemai Pendidikan Karakter Berbasis Budaya Dalam Menghadapi Tantangan Modernitas, in : PROSIDING SEMINAR Nasional di Institut Hindu Dharma, http:// file. Upi.edu. (accses date 5 September 2020)

[18] Hidayat dan Abdillah.2019. Ilmu Pendidikan "Konsep, Teori dan Aplikasinya. Medan : LPPI, pp, 30

[19] Diponogoro, Miranda dkk. 2010. Model Pendidikan Karakter di Universitas Indonesia. Jakarta: Kementrian Pendidikan Nasional.

[20] Hadiyatullah, Syahrul, Yusuf, Nurbani dan Zuriah, Nurul, 2018. Penumbuhan Rasa Nasionalisme Dan Cinta Budaya Indonesia Melalui Program "Kamsi" Pada Siswa SMP Negeri 1 Batu, in : Civic Hukum Journal, Volume 3, Nomor 1, Mei 2018.

[21] Muslich, Masnur. 2011, Pendidikan karakter, Jakarta: Bumi Aksara, pp.3

[22] Pahlavi, Iva Kurnia Anisabani, Peningkatan Rasa Cinta Budaya Dengan Mata Pelajaran Batik Di Sd Negeri Jageran, in : http: //ivakurniaap. Blogs .uny.ac.id/ (accses date 5 September 2020)

[23] Rakhmat, Cece, tt. Menyemai Pendidikan Karakter Berbasis Budaya Dalam Menghadapi Tantangan Modernitas, in : PROSIDING SEMINAR Nasional di Institut Hindu Dharma, http:// file. Upi.edu. (accses date September 2020), pp. 2

[24] Reni Alfiyah, Jayusman, Mukhamad Shokheh, 2017. Peran Guru Sejarah dalam Pengembangan Karakter Siswa Melalui Pembelajaran Sejarah Lokal di SMA Negeri 1 Ambarawa, in : IJHE Journal, 5 (2).

[25] Hasan, S. Hamid, 2012. Pendidikan Sejarah Untuk Memperkuat Pendidikan Karakter, ini : Paramita Journal, Vol. 22 No. 1 - Januari 2012 [ISSN: 0854-0039], pp.87 
[26] Zahroa , Sumardib , Marjono, 2017. The Implementation Of The Character Education In History Teaching, in : Historica Journal ISSN No. 2252-4673 Volume. 1 (2017) Issue. 1, pp.6.

[27] Hudaidah, 2014.Historical Thinking, Keterampilan Berpikir Utama, dalam Crisetra, Ejournal.unsri.ac.id, pp.10

[28] Subianto, Jito. 2013.Peran Keluarga, Sekolah, Dan Masyarakat Dalam Pembentukan Karakter Berkualitas, in ; Edukasia Jurnal Penelitian Pendidikan Islam, Vol. 8, No. 2, Agustus 2013, pp. 331.

[29] Hasan, S. Hamid, 2012. Pendidikan Sejarah Untuk Memperkuat Pendidikan Karakter, in : Paramita Journal Vol. 22 No. 1 - Januari 2012 [ISSN: 0854-0039]. 81-95, pp.85

[30] Ummasih, TT. Peran Strategis Pendidikan Sejarah Dalam Pembentukan Karakter Bangsa, Seminar Nasional, in : Conference paper on "Pendidikan Ilmu-Ilmu Sosial Membentuk Karakter Bangsa Dalam Rangka Daya Saing Global”, pp. 478.

[31] Agustin, Dyah Satya Yoga 2011. Penurunan Rasa Cinta Budaya Dan Nasionalisme Generasi Muda Akibat Globalisasi, in: jsh Sosial Humaniora journal, Vol 4 No. 2, November 201, pp. 78

[32] Surani, S, Bambang dan Narimo, Sabar, 2016. Pengelolaan Pendidikan Karakter Bangsa Berbasis Budaya Jawa Di Tk Negeri Pembina Surakarta, in: Managemen Pendidikan Journal- Vol. 11, No. 2, Juli 2016: 186-195, pp. 190.
[33] 31 Agustus 2009. Perlindungan Budaya Lemah, in: Kompas Newspaper.

[34] Koentjaraningra, 1984. Pengantar Antropologi Pokok-Pokok Etnografi II. Jakarta.Rineka Cipta, pp. 9

[35] Isputaminingsih, dan Hudaidah, 2013.

Pengembangan Bahan Ajar Sejarah Berbasis Sejarah Lokal, in : Universitas Sriwijaya Research Report, pp. 6

[36] Hildigardis M. I. Nahak, 2019. Upaya Melestarikan Budaya Indonesia Di Era Globalisasi, in: S o s i o log i Nus a n t a r a Journal, V o 1.5 , No. 1, T a h un 2019 , pp. 71

[37] Pekerti, Widia, dkk. 2008. Metode Pengembangan Seni. Jakarta: UT, pp. 11-51

[38] Harada, Tomohito. 2005. Consistency Of History Curriculum In Primary and Secondary School. In : Studi Sosial Journal Vol 1.Yogyakarta: Hispisi, pp. 33

[39] Cahyaningrum, Nugraheni, dan Sukestiyarno, 2016. Pembelajaran React Berbantuan Modul Etnomatematika Mengembangkan Karakter Cinta Budaya Lokal Dan Meningkatkan Kemampuan Pemecahan Masalah, in : Unnes Journal of Mathematics Education Research 5 (1) 2016, hlm. 52

[40] Purwantari, 31 Agustus 2009. Menakar Kecintaan Budaya Lokal, in: Kompas Newspaper. Bandung: CV Alfabeta, p. 89.

[41] Daryanto.2013. Inovasi Pembelajaran Efektif. Bandung: Yrama Widya, pp. 172 